\title{
Cohesion Markers in Children's Story Books
}

\author{
Tatik Irawati ${ }^{1}$, Mangatur Rudolf Nababan ${ }^{2}$, Riyadi Santosa ${ }^{3}$, Diah Kristina ${ }^{4}$ \\ 1,2,3,4 Universitas Sebelas Maret \\ Surakarta, Indonesia \\ $\{1$ tatikirawati@student.uns.ac.id\}
}

\begin{abstract}
Cohesion is a lexical or grammatical link between the lexicographic elements in the text. The purpose of this study to explain and analyze the application of cohesion to children's story books that have simple and effective word and sentence structures. Applying the right cohesion will make it easier for readers to understand the contents of the story. The method used qualitative with embedded case study; researchers determine in advance before taking data so that everything has been prepared from the beginning. The design is flexible and open because the research can develop continuously during data collection. The finding of this research of grammatical cohesion (reference pronoun $20 \%$, reference demonstrative $5 \%$, reference definite article $2 \%$, substitution $2 \%$, ellipsis $2 \%$, conjunction 18\%). For lexical cohesion (repetition $20 \%$, synonym $10 \%$, contrast opposition antonyms $7 \%$, contrast series scales $1 \%, 5 \%$ contrast series cycles, class-member $1 \%$, co-class $1 \%$, whole-part $5 \%$ and co-part $1 \%$.
\end{abstract}

Keyword: Cohesion markers, children's story book, linguistics study

\section{INTRODUCTION}

Cohesion markers are very important in children's story books because they function to connect between parts of the text to be cohesive, connecting between several different texts. The goal is to arrange so that there is a connection between words and sentences in a paragraph [12], [1], [7], [2], [11]. Cohesion markers are divided into two parts, namely lexical and grammatical. The markers of lexical cohesion consist of repetition, synonyms, contrast opposition antonyms, contrast opposition converseas, contrast series scales, contrast series cycles, class-member, class-co class, part whole-part, part co-part. Then proceed with a marker of grammatical cohesion namely reference (pronominals, demonstratives, definite articles, comparatives), substitutions, ellipsis, conjunction. As one of the features of the text, the position of the cohesion marker is very important because the marker can distinguish between text and not text. Its formation in the text requires the help of cohesive devices (cohesive device) instead of the text does not require the marker.

Children's stories are the most dominant aspect in improving children's development abilities. By providing children's story books, it is hoped that they can improve aspects of language, cognitive, emotional, social and creativity. The importance of children's story books in the development process is because in the book the shape is unique and able to provide pleasure, so that children easily learn and imitate the positive things contained in the content of the story. Furthermore, it is also explained that books can develop children's imagination and help them manage nature and connect with humans can also affect children in their lives later 
[3]. Children's story books are activities between parents and children [15] that provide a source of vocabulary that is richer than everyday conversation [13]. Some studies show that illustration styles influence how well children learn from books [5], [6]. However, little is known about how the number of illustrations affects learning. The experiment is currently investigating how quickly children learn new words from story books when they see one or two pictorial scenes at a time.

Children who have not been able to read, they try to understand the contents of the story through illustrations [18]. In a study by [8] found that pre-school aged 4-year-olds looked longer on illustrations than writing with complicated texts, it showed that before children read their storybooks, they first saw a picture illustration. [4] The found that even with various illustrative styles, preschoolers spend most of their time looking at illustrations and only $6 \%$ of the time they see texts [16]. Children aged 4-6 years have an interest in story books even though they have not been able to read fluently like adults. Children at the age of 4-6 years have begun to show their reading skills even though they are not fluent and they are still in spelling stage, while children 5-6 years have started to be able to read more smoothly even though sometimes, they still spell a little, especially the words they just know. When faced with illustrated story books, children at 4 years old mostly look at pictures then turn pages to the next page to see the next picture and tend to ignore the writing that accompanies the story while children aged 5-6 years with better reading skills besides seeing the picture also reads the writing but when they find letters that they don't recognize or are difficult to spell, they tend to jump over the part and if it happens too often they will get bored, stop reading the writing and finally look at the picture [19].

Reading habits for children are important because reading is one of the most important cognitive activities of humans. The interest in reading starts from childhood and develops with encouragement from adults who are close to children [9]. In general, picture books contain artistic images and topics related to life, education, emotions, imagination, creativity, and culture [9]. A picture book is characterized by narrative stories through the use of visual descriptions and words in the same proportion [10]. Children's literature is an educational tool [14]. Children's Books support the development of children's literacy skills and help them develop an understanding of the world and social norms. Children's books have a didactic structure, either explicit or implicit, the aim is to benefit children and help them build reading skills and also help them understand what they have read [14]. The purpose of this study is to find out the application markers of grammatical and lexical cohesion in children's story books, so conclusion can be drawn to be used as a reference in future studies.

\section{METHODOLOGY}

The research design used is qualitative research (embedded case study) with a descriptive approach (describing, analyzing, interpreting), prescriptive and SFL (Systemic Functional Linguistics). The data source of children's story book by Beatrix Potter which consists of 11 story series namely (1) The Tale of Petter Rabbit, seri (2) The Tale of Tom Kitten, seri (3) The Tale of Jemmima Puddleduck, seri (4) The Tale of Squirrel Nutkin, seri (5) The Tale of Benjamin Bunny, seri (6) The Tale of The Flopsy Bunnies, seri (7) The Tale of Mrs. Tigy-Winklem, seri (8) The Tale of Tow Bad Mice, seri (9) The Tale of Johny Town-Mouse, seri (10) The Tale of Mr. Jeremy Fisher, seri (11) The Tale of Mrs. Tittlemouse. 


\section{FINDINGS AND DISCUSSION}

The finding of this researh of grammatical cohesion (reference pronoun $20 \%$, reference demonstrative $5 \%$, reference definite article $2 \%$, comparatives 0 , substitution $2 \%$, ellipsis $2 \%$, conjunction $18 \%$ ). For lexical cohesion (repetition $20 \%$, synonym $10 \%$, contrast opposition antonyms $7 \%$, contrast opposition converses 0 , contrast series scales $1 \%, 5 \%$ contrast series cycles, class-member $1 \%$, co-class $1 \%$, whole-part $5 \%$ and co-part $1 \%$ ).

\section{a. Sample data of gramatical cohesion in reference pronomina}

Reference pronouns are categories of grammatical cohesion and the function to replace nouns. It can occupy a position which is generally occupied by nouns, such as subjects, objects, and in certain sentences it can also predicates. Another feature possessed by the pronouns is that the reference can vary depending on who is the speaker or writer, listener or speaker, and who or what is discussed. One type of pronoun is the personal pronoun." Once upon a time there were four little Rabbits, and their names were-Flopsy, Mopsy, Cotton-tail And Peter "(story 1, page 2, data number 1). Their replace to four little Rabbits to avoid repetition of words so that the sentence used is more effective. "An old mouse was running in and out over the stone doorstep, carrying peas and beans to her family in the wood. Peter asked her way to the gate, but she had such a large pea in her mouth that she could not answer. She only shook her head at him. Peter began to cry"(story 1, page 20-b, data number 50). She refers to an old mouse replacing the subject so that the sentences are used more smoothly. "Mr. McGregor hung up the little jacket and the shoes for a scare-crow to frighten the blackbirds. Peter never stopped running or looked behind him till he got home to the big fir-tree" (story 1, page 24, data number 75). Him Pronominal refers to Peter as a sentence object.

\section{b. Sample data of grammatical cohesion in reference demonstratives}

Reference demonstratives are used to designate small or large numbers of objects or people, this, these, that, those. Sentence example is "First she scrubbed their faces (this one is Moppet). Then she brushed their fur, (this one is Mittens). Then she combed their tails and whiskers (this in Tom Kitten). Tom was very naughty, and he scratched"(story 2, page 3-5) data number 10). "In the middle of the lake there is an island covered with tress and nut bushes; and amongst those trees stands a hollow oak-tree, which is the house of an owl who is called Old Brown" (story 4, page 2, data number 6). In linguistics the use of this and those like the data function as clues. Determiners themselves are words that start a noun, so that a noun becomes general or specific. General in the sense that all objects or people enter into it, and specifically means only certain objects or people intended by the speaker. This is used for single nouns that are close to the speaker. Thos are used for many objects that are far from the speaker

\section{c. Sample data of grammatical cohesion in definite articles}

Definite Article is a specific article that is used on a specific or previously mentioned thing, or to specify a noun in particular generally including objects, people, ideas, or thoughts. "The gentlemen raised his eyes above his newspaper and looked curiously at Jemima. "Madam, have you lost your way?" Said he. He had a long bushy tail which he was sitting upon, as the stump was somewhat damp" (story 3, page 9, data number 36). The word "the" is used when a noun mentioned in the previous sentence and what is meant is "fox". "In the middle of the lake there 
is an island covered with tress and nut bushes; and among those trees stands a hollow oak-tree, which is the house of owl who is called Old Brown" (story 4, page 2, data number 5). The word "the" is used when specified by a situation where something in question is clear.

\section{d. Sample data of grammatical cohesion in Substitution and Ellipsis}

Substitution is a grammatical relationship; it is not in the sentence. The core clause element is subject and verb. Based on the filler word category verb, the clause can be distinguished by noun clause, verb clause, adjective clause, adverb clause, proposition clause and numeral clause. "There were three creepy crawling people hiding in the plate-rack. Two of them got away; but the littlest one he caught" (story 11, page 10-a, data number 103). 'Now my dears, 'said old Mrs. Rabbit one morning, 'you may go into the field or down the lane, but don't go into Mr. McGregor's garden: your Father had an accident there; he was put in a pie by Mrs. McGregor. ' Now run along, and get into mischief. I am going out (story 1, page 3-4, data number 88). "I have not the patience to sit on a nest for twenty eight days; and no more have you Jemima. You would let them go cold; you know you would! (story 3, page 2, data number 144). In the example data one explains the purpose of one of them, while there is a substitution of Mr. McGregor's garden and no more have you been the substitution of to sit on a nest.

Ellipsis is a type of grammatical cohesion which is in the form of a certain lingual unit disappearance or omission mentioned earlier. The elements that are applied are in the form of words, phrases, clauses and sentences consisting of nominal ellipsis, verbal ellipsis, clause ellipsis. "Then old Mrs. Rabbit took a basketball and her umbrella, and went through the wood to the baker's. She buys a loaf of brown bread and five currants buns" (story 1, page 5, data number 89). In this example the word "bought" disappears after the "and" conjunction, but the meaning is the same: buying fresh bread and buying raisin bread." Old lady Rabbit was a window; she earned her living by knitting rabbit-wool mittens and muffineers. She also sold herbs, and rosemary tea, and rabbit-tobacco (which is what we call lavender). (Story 5, page 3, data number 79). The context is She also sold herbs, and sold rosemary tea, and sold rabbittobacco (which is what we call lavender)

\section{e. Sample data of grammatical cohesion in Conjunction}

Conjunction is divided into two, namely external and internal conjunction where the functions and rules of use can be seen in table 1 below.

\begin{tabular}{|l|l|l|}
\hline & External conjunction & Internal conjunction \\
\hline Addition & $\begin{array}{l}\text { Adding activities (and, beside, } \\
\text { both..and, or, either,...or, if not, } \\
\text { then) }\end{array}$ & $\begin{array}{l}\text { Adding arguments (furthermore, } \\
\text { moreover, in addition, or, } \\
\text { alternatively, now, well, alright, okay, } \\
\text { anyway, anyhow, by the way) }\end{array}$ \\
\hline Comparison & $\begin{array}{l}\text { Comparing and contrasting } \\
\text { events, things and qualities (like, } \\
\text { as if, even, whereas, while, instead } \\
\text { of, in place of, rather than, except } \\
\text { than, other than, apart of) }\end{array}$ & $\begin{array}{l}\text { Comparing and contrasting arguments } \\
\text { and evidence (similarly, again, that is, } \\
\text { i,e.,for example, for instance,e.g. in } \\
\text { general, in particular, in short, in } \\
\text { fact,indeed, at least, rather, by } \\
\text { contrast, on the other hand, } \\
\text { conversely, even) }\end{array}$ \\
\hline
\end{tabular}




\begin{tabular}{|l|l|l|}
\hline Time & $\begin{array}{l}\text { Ordering events in time (after, } \\
\text { since, now that, before, once, as } \\
\text { soon as, until) }\end{array}$ & $\begin{array}{l}\text { Ordering arguments in a text (first, } \\
\text { second, third, finally, lastly, at the } \\
\text { same time, still) }\end{array}$ \\
\hline Consequence & $\begin{array}{l}\text { Explaining why and how events } \\
\text { happen (because, so (that), } \\
\text { therefore, although, even though, } \\
\text { but, however, by, thus, even by, } \\
\text { but, so that, in order to, in ace, } \\
\text { even so, without, lest, for fear of, } \\
\text { arguments (thus, hence, accordingly, } \\
\text { in conclusion, after all, anyway, } \\
\text { even if, even, then, unless }\end{array}$ & $\begin{array}{l}\text { anyhow, in any case, at any rate, } \\
\text { admittedly, of course, needless to say, } \\
\text { nevertheless, nonetheless, still) }\end{array}$ \\
\hline
\end{tabular}

Examples of data in the story of "Moppet and Mittens walking down the garden path unsteadly. Presently they are happy with their hearts and fell on their noses. When they stood up there were several green smears!" (Story 2, page 9, data number 82). And is external conjunction adding additives. "Mittens laugehd so that she felt off the wall. Moppet and Tom descended after her; the pinafores and all the rest of Tom's clothes came off on the way down "Come! Mr. Drake Puddle-Duck,: said Moppet- "Come and help us to dress him! Come and button up Tom "(Story 2, page 16, data number 93) So that is external conjunction purpose desire expectant. "What a funny sight it is to see a boord of ducklings with a hen! Listen to the story of Jemima Puddle Duck, who was annoyed because the farmer's wife would not let her hatch her own eggs "(Story 3, page 1, data number 145) because is the internal conjunction cause expectant. The squirrels are filled with their little sacks with nuts. But Nutkin sat upon a big flat rock, and played ninepins with a crab apple and green cones (Story 4, page 18, data number 81) But is internal conjunctive means concessive.

Lexical Cohesion

Table. 2

\begin{tabular}{|c|c|c|c|c|c|c|c|c|c|}
\hline \multicolumn{10}{|c|}{ Taxonomic Relation } \\
\hline \multirow{3}{*}{$\begin{array}{l}\text { Repetiti } \\
\text { on }\end{array}$} & \multirow{3}{*}{$\begin{array}{l}\text { Synony } \\
\mathrm{ms}\end{array}$} & \multicolumn{4}{|c|}{ Contrast } & \multicolumn{2}{|c|}{ Class } & \multicolumn{2}{|c|}{ Part } \\
\hline & & \multicolumn{2}{|c|}{ Oppositions } & \multicolumn{2}{|c|}{ Series } & \multirow{2}{*}{$\begin{array}{l}\text { Class- } \\
\text { member }\end{array}$} & \multirow{2}{*}{$\begin{array}{l}\text { Co- } \\
\text { class }\end{array}$} & \multirow{2}{*}{$\begin{array}{l}\text { Whol } \\
\text { e-part }\end{array}$} & \multirow{2}{*}{$\begin{array}{l}\text { Co- } \\
\text { part }\end{array}$} \\
\hline & & $\begin{array}{l}\text { Antony } \\
\mathrm{ms}\end{array}$ & $\begin{array}{l}\text { Convers } \\
\text { eas }\end{array}$ & $\begin{array}{l}\text { Scal } \\
\text { es }\end{array}$ & $\begin{array}{l}\text { Cycle } \\
\text { S }\end{array}$ & & & & \\
\hline $\begin{array}{l}\text { e.g: } \\
\text { Marry } \\
\text { Married } \\
\text { Marriag } \\
\text { e }\end{array}$ & $\begin{array}{l}\text { e.g: } \\
\text { Marriag } \\
\text { e } \\
\text { Weddin } \\
\text { g }\end{array}$ & $\begin{array}{l}\text { e.g: } \\
\text { Marriag } \\
\text { e } \\
\text { Divorce }\end{array}$ & $\begin{array}{l}\text { e.g: } \\
\text { Wife } \\
\text { Husband }\end{array}$ & $\begin{array}{l}\text { e.g: } \\
\text { Hot } \\
\text { War } \\
\text { m } \\
\text { Tepi } \\
\text { d } \\
\text { Cold }\end{array}$ & $\begin{array}{l}\text { e.g: } \\
\text { Sunda } \\
\text { y } \\
\text { Mond } \\
\text { ay } \\
\text { Tuesd } \\
\text { ay }\end{array}$ & $\begin{array}{l}\text { e.g: } \\
\text { Relations } \\
\text { hip } \\
\text { Marriage }\end{array}$ & $\begin{array}{l}\text { e.g: } \\
\text { Marria } \\
\text { ge } \\
\text { Friensh } \\
\text { ip }\end{array}$ & $\begin{array}{l}\text { e.g: } \\
\text { Body } \\
\text { Arms } \\
\text { Hans }\end{array}$ & $\begin{array}{l}\text { e.g: } \\
\text { Face } \\
\text { Han } \\
\text { ds } \\
\text { Eyes } \\
\text { Thro } \\
\text { at } \\
\text { Head } \\
\text { Brai } \\
\text { n }\end{array}$ \\
\hline
\end{tabular}

Repetition of data in the children's story book 'Now my dears, ' said old Mrs. Rabbit one morning, 'you may go into the felds or down the lane, but don't go into Mr. McGregor's garden: your Father had an accident there; he was put in a pie by Mrs. McGregor. 'Now run along, and get into mischief. I am going out (story 1, page 3-4, data number 3). Flopsy, Mopsy, and Cotton-tail, who were good little bunnies, went down to the lane to gather blackberries; (story 
1, page 6, data number 3). In story 1 there is a repetition of the word the lane and the meaning in the sentence is the same. Then proceed to data synomys "Once upon a time there were three little kittens, and their names were Mitthens, Tom Kitten, and Moppet. They have dear little fur coats of their own; and they tumbled about the doorstep and played in the dust "(story 2, page 1, data number 24). "Moppet and Mittens walked down the garden path unsteadly. Presently they are happy with their hearts and fell on their noses. When they stand up there are several green smears! "(Story 2, page 9, data number 24) tumbled and fell are synomys. Followed by contrast data opposition antonyms "Mr. McGregor came up with a sieve, which he intended to pop upon the top of Peter; but Peter wriggled out just in time, leaving his jacket behind him (story 1, page 15, data number 31). 'Now my dears,' said old Mrs. Rabbit one morning, 'you may go into the field or down the lane, but don't go into Mr. McGregor's garden: your Father had an accident there; he was put in a pie by Mrs. McGregor. 'Now run along, and get into mischief. I am going out (story 1, page 3-4, data number 31) On this data came up is contrast opposition antonyms with going out.

In the lexical cohesion contrast series cycles, the function is to explain something contrary to the meaning of 'Now my dears, 'said old Mrs. Rabbit one morning, 'you may go into the felds or down the lane, but don't go into Mr. McGregor's garden: your Father had an accident there; he was put in a pie by Mrs. McGregor. 'Now run along, and get into mischief. I am going out (story 1, page 3-4, data number 34). Then old Mrs. Rabbit took a basketball and her umbrella, and went through the wood to the baker's. She buys a loaf of brown bread and five currents buns (story 1, page 5, data number 34). Now explained the instructions at that time, Then explained the next activity that would be carried out by the rabbit mother. Then the data on the contrast series scales serves to explain the sequence, which is "First she scrubbed their faces (this one is Moppet). Then she brushed their fur, (this one is Mittens). Then she combed their tails and whiskers (this in Tom Kitten). Tom is very naughty, and he scratched "(story 2, page 3-5, data number 27). "Then Tabitha came to the garden and found her kittens on the wall with no clothes" (story 2, page 201, data number 27). First, then is contrast series scales and the context is to explain the sequence of events. Another example is found in data story 4, page 8 , data number 43 "by the next morning" story 4, page 12, data number 43 "on the third day" story 4, page 14, data number 43 "on the forth day "Story 4, page 16, data number 43" on the fifth day "story 4, page 19, data number 43 " on the sixth day".

Class consists of class and co-class found in story 1 data, page 22, data number 28 "saw" functions as general class whereas those that function as co-class are "staring" in story 1, page 21, data number 28 In the word "fell" which functions as general class, story 2, page 9, while data number 26, "fell down" story 2, page 10, data number 26, "fell off" story 2, page 12, data number 28 both function as co-classes. Then the story 3 data, page 6, data number 58 "ran" is the general class. While the co-class is in story 3, page 19, data number 58 is "trotted down". There are also examples of data classes that function as co-classes in the sentence "A moment afterward there were most awful noises barking, baying, growls and howls, squealing and groans." (Story 3, page 23, data number 58). The context is when the Sound occurs when there is a commotion in the warehouse house when the colie dog frees Jemima from the fox.

Part consists of whole-part and co-part, for example in story 1, page 14, data number 27 "Tears" is a whole-part, while that which functions as a co-part is "sobs" story 1, page 14, data number 27 and "cry" story 1, page 20-b, data number 27. Story 3, page 11, data number 63, "He led the way to a very retired, dismal looking house amongst the fox-gloves" is a whole -part, while story 3, page 11, data number 63 "It was bulit of fagots and turf, and there were two broken pails, one on top of another, by way of a chimney" functioned as a co-part. 


\section{CONCLUSION}

Grammatical and lexical cohesion markers have their own characteristics in their uses and functions in sentences. If they are applied correctly, the order of words in the sentence becomes more easily understood and effective. Markers of cohesion play an important role in writing children's story books because linguistically there are inseparable elements in them. These markers are divided into very detailed sub-categories so that the application is able to accommodate the needs of the sentence in the story. In accordance with the results of the research, grammatical cohesion markers that are often used are references, whereas in the marker of lexical cohesion that often appears is repetition.

\section{References}

[1] Baker, M. (2001). In other words a course book on translation. USA and Canada : Routlegde.

[2] Baker, M. (2018). In other words a course book on translation. USA and Canada :Routlegde.

[3] Cullinan, B. (1989). Literature and the child. New York: Harcourt Brace Jovanovich.

[4] Evans, M. A., \& Saint-Aubin, J. (2005). What children are looking at during shared storybook reading: Evidence from eye movement monitoring. Psychological Science, 16 (11), 913-920. https://doi.org/10.1111/j.1467-9280.2005.01636.x CrossrefPubMedWeb of Science ${ }^{\circ}$ Google Scholar.

[5] Ganea, P. A., Canfield, C. F., Simons-Ghafari, K., \& Chou, T. (2014). Do cavies talk? The effect of anthropomorphic picture books on children's knowledge about animals. Frontiers in Psychology, 5(283). https://doi.org/10.3389/fpsyg.2014

[6] Ganea, P. A., Pickard, M. B., \& DeLoache, J. (2008). Transfer between picture books and the real world by very young children. Journal of Cognition and Development, 9(1), 46 66. https://doi.org/10.1080/15248370701836592.

[7] Halliday, M. A. K. \& Matthiessen, Christian. (2014). An introduction to functional grammar. London: Arnold.

[8] Justice, L. M., Skibbe, L. E., Canning, A., \& Lankford, C. (2005). Pre-schoolers, print and storybooks: An observational study using eye movement analysis. Journal of Research in Reading, 28 (3), 229-243. https://doi.org/10.1111/j.1467-9817.2005.00267.x.

[9] Lin, R. (2012). A study of curriculum innovation teaching and creative thinking for picture book creation. IERI Procedia, 2, 30-35.

[10] Lynch-Brown, C. (1993). Essentials of children's literature. Boston, MA: Allyn-Bacon

[11] Martin \& Rose. (2007). Working with discourse meaning beyond the clause. London.

[12] Martin, J. R. (1992). English text: system and structure. Philadelphia/Amsterdam: John Benjamins Publishing Company.

[13] Montag, J. L., Jones, M. N., \& Smith, L. B. (2015). The words children hear: Picture books and the statistics for language learning. Psychological Science, 26(9), 1489 1496. https://doi.org/10.1177/0956797615594361.

[14] Puurtinen T. (1998). Syntax, readability and ideology in children's literature. Meta: Translators'Journal, 43(4), 524-533. http://dx.doi.org/10.7202/003879ar.

[15] Rideout, V. J., Vanderwater, E. A., \& Wartella, E. A. (2003). Zero to six. In Electronic media in the lives of infants, toddlers and preschoolers. Menlo Park, CA: The Kaiser Family Foundation. Google Scholar 
[16] Roy-Charland, A., Saint-Aubin, J., \& Evans, M. A. (2007). Eye movements in shared book reading with children from kindergarten to Grade 4. Reading and Writing, 20(9), 909 931. https://doi.org/10.1007/s11145-007-9059-9CrossrefGoogle Scholar.

[17] Santosa, R. (2017). Metode penelitian kualitatif kebahasaan. UNS Press

[18] Wagner, L. (2013). By the numbers: A quantitative content analysis of children's picture books. Frontiers in Psychology, 4(850). https://doi.org/10.3389/fpsyg.2013.00850

[19] Yuliana, Gogor \& Hen (2013). Perancangan buku bergambar dan genuai untuk anak usia 4-6 tahun. (Tesis). https://media.neliti.com/media/publications/87190-ID-none.pdf 